\title{
DATA REPORT: 42. GEOCHEMICAL RESULTS FROM WIRELINE LOGS IN THE CELEBES SEA, SITES 767 AND 770 OF LEG $124^{1}$
}

\author{
Elizabeth Lewis Pratson, ${ }^{2}$ Cristina Broglia, ${ }^{2}$ Garrett W. Brass,${ }^{3}$ and Richard D. Jarrard ${ }^{2}$
}

\begin{abstract}
Geochemical well logs were obtained at ODP Sites 767 and 770 in the Celebes Sea. The log data obtained at sea have been corrected for borehole size changes, the effects of drilling fluids, and logging-speed variations. The processed logs are then used to calculate the amounts of the three major radioactive elements (Th, $\mathrm{U}$, and $\mathrm{K}$ ) and the dry weight percentages of oxides every $0.1524 \mathrm{~m}$ throughout the logged intervals. Numerous oxide core measurements were made for Site 767 and for the basement section of Site 770 . Core and log measurements of $\mathrm{CaO}$, $\mathrm{Al}_{2} \mathrm{O}_{3}, \mathrm{FeO}^{*}, \mathrm{~K}_{2} \mathrm{O}$, and $\mathrm{TiO}_{2}$ agree well. At both sites, however, the log-derived $\mathrm{SiO}_{2}$ is higher than that measured on cores. The discrepancy is due to the fact that $\mathrm{MgO}$ or $\mathrm{Na}_{2} \mathrm{O}$ could not be calculated from the logs, causing each of the elements measured by the geochemical tool to be slightly high, an effect that is most apparent in $\mathrm{SiO}_{2}$ because it makes up the greatest portion of the rock-forming elements.
\end{abstract}

\section{INTRODUCTION}

Leg 124 of the Ocean Drilling Program took place in the Celebes Sea, located in the extreme western Pacific Ocean. The study area is bounded by the Sulu Archipelago to the north, Borneo to the west, and Sulawesi to the south, all active tectonic features. The primary objective of Leg 124 was to study the marginal basins located in the area, to gain insight into their origins and histories. The nature of these basins is very complex due to surrounding active plate subduction and collision. Geochemical logs are useful in distinguishing lithologic changes because they measure the major rock-forming elements. Of the five sites drilled on Leg 124, two were logged with the geochemical logging tool string.

In this report we discuss first the hole conditions and logging operations at each of the logged sites. The basic principles of the geochemical tool and a description of the data processing techniques follows. The computed dry weight percentages of the major oxides are presented and compared to the available core data.

\section{DATA ACQUISITION}

To prepare for logging, a wiper trip was made in each of the logged holes. Seawater was then circulated to clean out fill at the bottom of the hole, and each hole was conditioned with a potassium chloride mud to inhibit clay swelling. Approximately $125 \mathrm{~m}$ of the upper portion of both Holes 767B and $770 \mathrm{C}$ was logged through pipe. Electrical and acoustical logs do not work through pipe, as electrical currents and sound waves do not propagate through steel. Neutrons and gamma rays, however, can pass or be detected through pipe; thus geochemical and radioactive logs can be recorded in this manner. However, when run in this manner, signal detected

\footnotetext{
${ }^{1}$ Silver, E. A., Rangin, C., von Breymann, M. T., et al., 1991. Proc, $O D P$, Sci. Results, 124: College Station, TX (Ocean Drilling Program).

${ }^{2}$ Lamont-Doherty Geological Observatory of Columbia University, Palisades, NY 10964, U.S.A.

${ }^{3}$ Division of Marine Geology and Geophysics, Rosenstiel School of Marine and Atmospheric Science, University of Miami, 4600 Rickenbacker Causeway, Miami, FL 33149-1098, U.S.A.
}

from the formation is greatly attenuated, resulting in a decreased signal-to-noise ratio. The through-pipe sections of Holes $767 \mathrm{C}$ and $770 \mathrm{~B}$ were processed; yet the data quality is not as high as that of the lower open-hole section of each hole. The overall data quality of the geochemical logs is good with the exception of the aluminum curve, which is severely affected by the variable logging speed caused by very sticky borehole walls.

In Hole $767 \mathrm{C}$ the first logging tool string was the seismic stratigraphic combination (long-spaced sonic, phasor resistivity, and natural gamma-ray tools). The tool string hit an impassible ledge at 295 meters below seafloor (mbsf); thus the tools were retrieved and the side-entry sub (SES) was added. A successful logging pass with this tool combination was then made open-hole from 548 to $125 \mathrm{mbsf}$ and through pipe from $125 \mathrm{mbsf}$ to $17 \mathrm{~m}$ above the seafloor. The geochemical logging string also returned data successfully with the SES, from 516 to $126 \mathrm{mbsf}$ open-hole and through pipe from 126 to $0 \mathrm{mbsf}$.

Originally only one site was planned for the Celebes Sea. Because basement objectives were not reached at Site 767, however, a second site (770), $23 \mathrm{nmi}$ north-northeast of Site 767 on a raised fault block, was drilled. Hole $770 \mathrm{C}$ reached a total depth of $529 \mathrm{mbsf}$, including $106 \mathrm{~m}$ of basement. After logging with the borehole televiewer, pipe was pulled to 100 mbsf and the SES was rigged up. The seismic stratigraphic combination (long-spaced sonic, phasor resistivity, and natural gamma-ray tools) was run open hole from 670 to $117 \mathrm{mbsf}$ and through pipe from 117 to 0 mbsf. Geochemical logs were recorded open-hole from 515.6 to $125.6 \mathrm{mbsf}$ and through pipe from 125.6 to $0 \mathrm{mbsf}$. Finally, the lithoporosity tool string (lithodensity, neutron porosity, natural gamma-ray tools), was run open-hole from 514.6 to $125.6 \mathrm{mbsf}$ and through pipe from 125.6 to $102.6 \mathrm{mbsf}$.

\section{GEOCHEMICAL TOOL STRING}

The geochemical logging tool (GLT) string consists of four separate logging tools: the natural gamma-ray tool (NGT), the compensated neutron tool (CNT), the aluminum activation clay tool, (AACT), and the gamma-ray spectrometry tool (GST; Figure 1; GLT, NGT, CNT, AACT, and GST are the trademarks of Schlumberger). The NGT is located at the top 


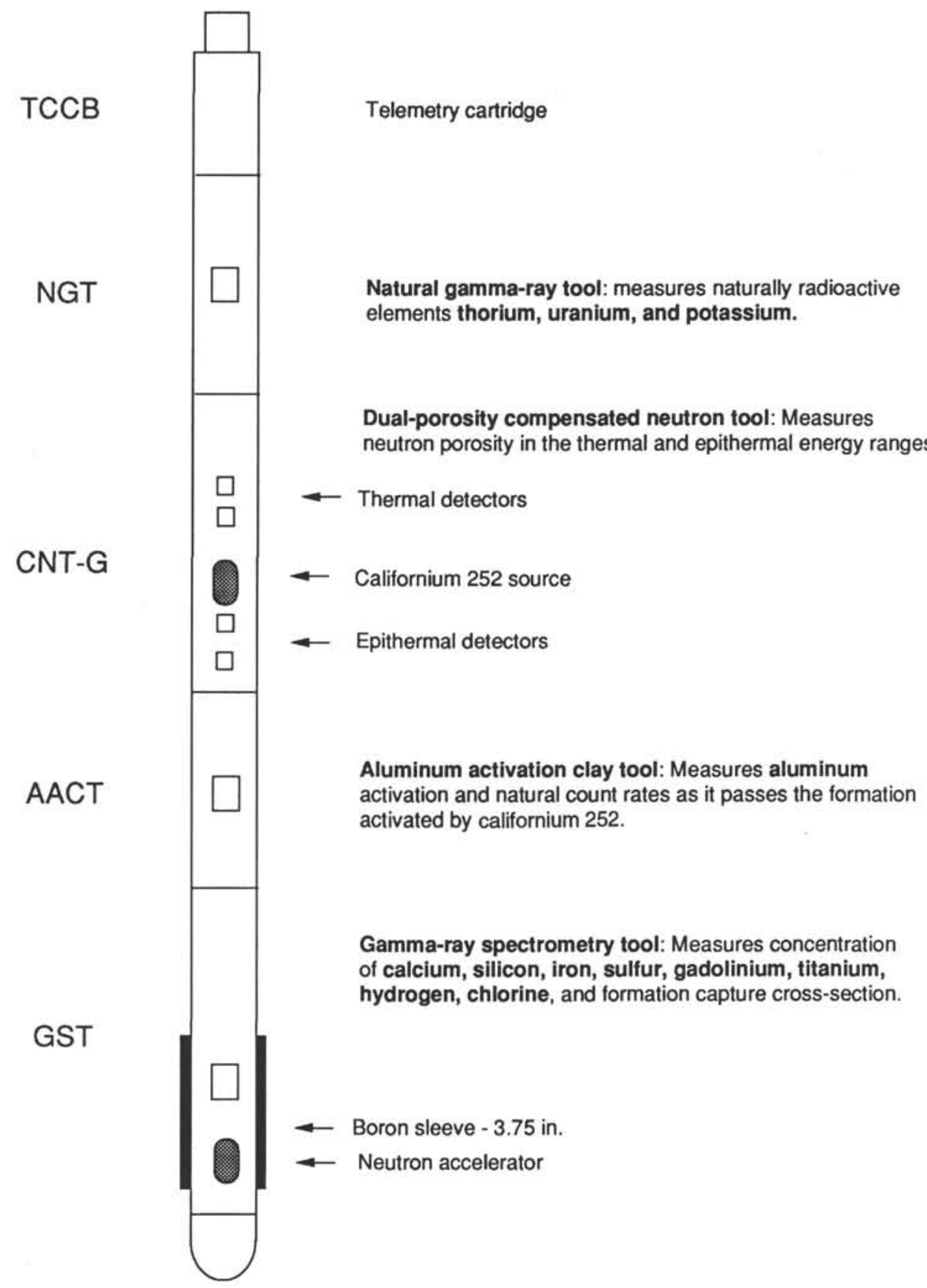

Figure 1. Schematic drawing of the geochemical logging tool string used in the Ocean Drilling Program.

of the tool string so that it can measure the naturally occurring radionuclides, $\mathrm{Th}, \mathrm{U}$, and $\mathrm{K}$, before the formation is activated by the nuclear sources mounted on following tools. The CNT is located below the NGT, carrying a low-energy neutron source $\left(\mathrm{Cf}^{252}\right)$ to activate the $\mathrm{Al}$ atoms in the formation. The AACT, a modified NGT, follows the ${ }^{252} \mathrm{Cf}$ source, measuring the activated gamma rays in the formation. By combining this measurement with the previous NGT measurement, the background radiation is subtracted out and a reading of formation $\mathrm{Al}$ is obtained (Scott and Smith, 1973). The gamma-ray spectrometry tool, located at the bottom of the string, carries a pulsed neutron generator to bombard the borehole and formation and a NaI scintillation counter to measure the spectrum of capture gamma rays generated by neutron-cap- ture reactions. Because each of the elements in the formation is characterized by a unique spectral signature, it is possible to derive the contribution (or yield) of the elements silicon ( $\mathrm{Si}$ ), iron $(\mathrm{Fe})$, calcium $(\mathrm{Ca})$, titanium $(\mathrm{Ti})$, sulfur $(\mathrm{S})$, gadolinium (Gd), and potassium (K), to the measured spectrum, and in turn to estimate their abundance in the formation. The GST also measures hydrogen $(\mathrm{H})$ and chlorine $(\mathrm{Cl})$ in the borehole and formation, but these elements are not used in determining the rock geochemistry.

The only major elements not measured by the geochemical tool string are magnesium $(\mathrm{Mg})$ and sodium $(\mathrm{Na})$. The neutron-capture cross sections of these elements are too small to be detected by the GST. A rough estimate of their abundances can be made using the photoelectric factor (PEF) from the 
lithodensity tool when available. This calculation was not done at either Hole 767B or 770C because the lithodensity tool was not run at Hole 767B or through pipe in the upper portion of Hole $770 \mathrm{C}$; therefore, estimating of $\mathrm{Mg}$ and $\mathrm{Na}$ in the lower part of the hole would have created an artificial boundary in the final oxides computation.

\section{DATA REDUCTION}

Well-log data from the Schlumberger tools are transmitted digitally up a wireline and are recorded and processed on the JOIDES Resolution in the Schlumberger Cyber Service Unit (CSU). The results from the CSU are made available as "field logs" for initial interpretation while at sea. Subsequent reprocessing is necessary to further correct the data for the effects of logging conditions, fluids added to the well, logging speed, and pipe effects. Processing of the spectrometry data is required to transform the relative elemental yields into oxide weight fractions.

The processing is done using a set of log interpretation programs written by Schlumberger. The processing steps are summarized below:

\section{(1) Reconstruction of Relative Elemental Yields from Recorded Spectral Data}

The first step in processing compares the measured spectra from the GST with a series of standard spectra to determine the relative contribution (or yield) of each element using a least-squares method. Whereas six elemental standards ( $\mathrm{Si}$, $\mathrm{Fe}, \mathrm{Ca}, \mathrm{S}, \mathrm{Cl}$, and $\mathrm{H}$ ) are used to produce the yields at sea, during the shore-based processing at Lamont-Doherty, the S standard is removed because the amount of $S$ in the formation is far below the resolution of the tool (Jarrard and Lyle, 1990) and two additional standards (Ti, Gd) are utilized. Although Ti and Gd are often at very low concentrations in the formation, they can make a large contribution to the measured spectra because of their large neutron-capture cross-sections. The capture cross-section of $\mathrm{Gd}$, for instance, is 49,000 barns compared, to that of $\mathbf{S i}$, which is $\mathbf{0 . 1 6}$ barns (Hertzog et al., 1987). Therefore Gd, although occurring in very small abundances in the formation, must be included when one is calculating to obtain a best-fit between the measured and the standard spectra. A potassium (K) standard may also be included in the inversion. We have found, however, that for the lithologies and hole conditions encountered in the ODP holes, the $\mathrm{K}$ standard causes the inversion to become unstable; thus it was left out of the solution. This best-fit analysis gives $\mathrm{Si}, \mathrm{Ca}, \mathrm{Fe}, \mathrm{Ti}, \mathrm{Gd}, \mathrm{H}$, and $\mathrm{Cl}$ as final yields.

Before any further manipulation of the yields is done, a 10 -point smoothing filter is applied to reduce the amplitude of noise in the data. In the case of data recorded through pipe the iron yield is corrected for effects caused by the steel in the drill pipe and bottom hole assembly by applying an appropriate offset for each pipe thickness.

\section{(2) Depth-shifting}

The second step depth-shifts the logging runs to a chosen reference run. A total gamma-ray curve (run on each tool string) is chosen as a reference curve based on cable tension (the logging run with the least amount of tool sticking) and cable speed (faster speeds are less affected by tool sticking). The logs were depth-referenced to the geochemical run at Hole 767B and to the seismic stratigraphic run at Hole 770C.

\section{(3) Calculation of Total Radioactivity, and Th, U, and K Concentration}

The third routine calculates the total natural gamma radiation in the formation and the concentrations of $\mathrm{Th}, \mathrm{U}$, and $\mathrm{K}$, using the counts in five spectral windows from the natural gamma ray tool (Lock and Hoyer, 1971). This resembles shipboard processing. Corrections for hole size changes are normally included in the shore-based processing of these curves; however, because a caliper run was not recorded at either Holes 767B or $770 \mathrm{C}$, corrections were made relative to a constant bit size of 9.875 in. A Kalman filter (Ruckebusch, 1983) is applied to correct for statistical errors in the logs, which often create erroneous negative readings and anticorrelations (especially between Th and $U$ ). At each depth level, calculations and corrections were also done for $\mathrm{K}$ contained in the mud. This $\mathrm{K}$ correction is particularly useful in the Ocean Drilling Program where $\mathrm{KCl}$ is routinely added to the hole, though because of dispersion, only a portion of what is added actually reaches the borehole. The outputs of this program are: $\mathrm{K}$ (wet-weight percentage), $\mathrm{U}$ (ppm), and Th (ppm), along with a total gamma-ray curve and a computed gamma-ray curve $(\mathrm{Th}+\mathrm{K})$.

\section{(4) Calculation of $\mathrm{Al}$ Concentration}

The fourth routine calculates an Al curve using four energy windows from the AACT, while simultaneously correcting for borehole fluid neutron-capture cross section, formation neutroncapture cross section, formation slowing-down length, and borehole size. Porosity and density logs are needed in this routine to convert the wet-weight percentage $\mathrm{K}$ and $\mathrm{Al}$ curves to dryweight percentage. In the case of Hole 767B, a porosity curve was calculated from the neutron measurement made on the geochemical tool string. Because this neutron tool carries a different source than the conventional neutron tool, the obtained curves give erroneous values that are useful only in a qualitative sense. The neutron porosity from the field logs was thus rescaled to match values obtained on the cores. From this porosity curve a density curve was then calculated using zoned matrix density values from core measurements (Shipboard Scientific Party, 1990a). At Hole 770C we used the neutron porosity curve, offset to match core values in the sediments and a sonic-derived porosity in the basalts. This curve was then used to calculate a density log using a zoned matrix density.

$\mathrm{A}$ correction is also made for $\mathrm{Si}$ interference with $\mathrm{Al}$. Si can become activated by the ${ }^{252} \mathrm{Cf}$ source, causing a reaction that produces the aluminum isotope ${ }^{28} \mathrm{Al}$ (Hertzog et al., 1987). Because this $\mathrm{Si}$ reaction creates a direct interference with the $\mathrm{Al}$ calculation, the program uses the Si yield from the GST to determine the silicon background correction. The program outputs a dry-weight percentage of $\mathrm{Al}$ and $\mathrm{K}$ that are used in the calculation and normalization of the remaining elements. The $\mathrm{Al}$ curve output by the program was found to be greatly affected by the uneven tension on the logging cable caused by frequent sticking of the tool string. Based on a small interval of good $\mathrm{Al}$ log data, a new Al curve was calculated based on the assumption of $\mathrm{Al}=3 \mathrm{~K}+2.2$ in the sediments. Original logs were salvaged and spliced in the basement section of Hole $770 \mathrm{C}$.

\section{(5) Normalization of $\mathrm{Al}$ and $\mathrm{K}$ with Elemental Yields to} Calculate the Elemental Weight Fractions

The next routine takes the dry weight percentage of $\mathrm{Al}$ and $\mathrm{K}$ and normalizes them with the reconstructed yields to obtain dry weight percentages of the elements using the relationship:

$$
W t_{\mathrm{i}}=F Y_{\mathrm{i}} / S_{\mathrm{i}}
$$

where:

$W t_{\mathrm{i}}=$ absolute elemental concentration.

$F=$ normalization factor.

$\mathrm{Yi}=$ relative elemental yield

$S_{\mathrm{i}}=$ tool spectral sensitivity. 
The normalization factor, $F$, is a calibration factor determined at each depth to account for the presence of $\mathrm{C}$ and $\mathrm{O}$ associated with each element. Because the sum of oxides in a rock is $100 \%, F$, is given by

$$
F\left(\Sigma X_{\mathrm{i}} Y_{\mathrm{i}} / S_{\mathrm{i}}\right)+X_{\mathrm{K}} \mathrm{Wt}_{\mathrm{K}}+X_{\mathrm{Al}} \mathrm{Wt}_{\mathrm{Al}}=100
$$

where:

$X_{\mathrm{i}}=$ dry weight percentage of oxide or carbonate divided by dry weight percentage of element $i$.

$Y_{\mathrm{i}}=$ fraction of spectra attributed to element $i$.

$S_{\mathrm{i}}=$ sensitivity factor.

$X_{\mathrm{K}}=$ dry weight percentage of oxide of element $\mathrm{K}$ divided by dry weight percentage of $\mathrm{K}$.

$W t_{\mathrm{K}}=$ dry weight percentage $\mathrm{K}$.

$X_{\mathrm{Al}}=$ dry weight percentage of oxide of element Al divided by dry weight percentage of $\mathrm{Al}$.

$W t_{\mathrm{Al}}=$ dry weight percentage $\mathrm{Al}$.

The sensitivity factor, $S_{\mathrm{i}}$, is a tool constant measured in the laboratory, which depends on the capture cross section of each element measured by the geochemical tool (Hertzog et al., 1987).

\section{(6) Calculation of Oxide Percentages}

The sixth and last routine simply multiplies the percentage of each element by its associated oxide factor (Table 1).

\section{COMPARISON OF LITHOLOGY AND CORES WITH GEOCHEMICAL LOGS}

\section{Site 767}

The processed natural gamma-ray curves from Hole 767B are shown in Figure 2. The natural gamma-ray tool is run on each of the two tool strings and each pass has been reprocessed. The logs presented in Figure 2 have been spliced to maximize the best data. The final logs primarily come from the geochemical logging tool pass, as this was run at the slowest speed for good statistical variations and was least affected by tool sticking. The interval from 0 to 79 mbsf comes from the geochemical run and has been corrected for pipe. The interval from 79 to 109 mbsf is from the acoustic-resistivity gamma-ray run, corrected for additional attenuation caused by the bottom-hole assembly. The remaining interval, 109-654 mbsf, comes from the geochemical logging string recorded openhole. A few spikes, due to activation by the ${ }^{252} \mathrm{Cf}$ source, are marked by asterisks in Figure 2. The results match the lithologic core description well (Shipboard Scientific Party, 1990a). Unit IIA shows a decrease in $\mathrm{K}$ values relative to surrounding Units I and IIB, as would be expected by the additional carbonate content of this unit. Unit III is marked by an increase in both $\mathrm{K}$ and $\mathrm{Th}$ content, primarily due to the presence of illitic clays (Shipboard Scientific Party, 1990a).

Figure 3 compares the oxide weight fractions estimated from the logs, to XRF measurements. The $\mathrm{SiO}_{2}$ values from the logs are approximately $10 \%$ higher than those from cores,

Table 1. Oxide factors used to normalize elements to $100 \%$ and convert elements to oxides.

\begin{tabular}{llc}
\hline Element & Oxide/carbonate & Conversion factor \\
\hline $\mathrm{Si}$ & $\mathrm{SiO}_{2}$ & 2.139 \\
$\mathrm{Ca}$ & $\mathrm{CaO}$ & 1.399 \\
$\mathrm{Fe}$ & $\mathrm{FeO}^{*}$ (total iron) & 1.358 \\
$\mathrm{~K}$ & $\mathrm{~K}_{2} \mathrm{O}$ & 1.205 \\
$\mathrm{Ti}$ & $\mathrm{TiO}_{2}$ & 1.668 \\
$\mathrm{Al}$ & $\mathrm{Al}_{2} \mathrm{O}_{3}$ & 1.899 \\
\hline
\end{tabular}

which may be explained by the lack of $\mathrm{MgO}$ and $\mathrm{Na}_{2} \mathrm{O}$ estimates from the logs. Good agreement between logs and cores exists for $\mathrm{FeO},{ }^{*} \mathrm{Al}_{2} \mathrm{O}_{3}$, and $\mathrm{K}_{2} \mathrm{O}$.

\section{Site 770}

The processed natural gamma-ray logs from Hole $770 \mathrm{C}$ are displayed in Figure 4. The data come from the sonic-resistivity run, corrected for pipe attenuation in the upper $125 \mathrm{~m}$. The overall character of the logs shows a general agreement with the lithologic description (Shipboard Scientific Party, 1990). Unit I is characterized by a lower total gamma-ray value. Unit II displays a higher total gamma-ray value and a marked increase in thorium related to the clay content. The sedimentbasement contact is characterized by a sharp decrease in total gamma-ray, $\mathrm{K}$, and Th curves.

The oxide weight fractions in the sediment section are shown in Figure 5 . Unit I ( 0 to 280 mbsf on the logs) is distinguished from Unit II by a lower $\mathrm{K}_{2} \mathrm{O}$ value. The subdivision of Unit II into three subunits based on the $\mathrm{CaCO}_{3}$ content (Shipboard Scientific Party, 1990b) is also reflected by the $\mathrm{CaO}$ curve estimated from the logs.

In the basement section of the well, the log values agree well with the core values except for those of $\mathrm{K}_{2} \mathrm{O}$ and $\mathrm{SiO}_{2}$. The log-derived $\mathrm{SiO}_{2}$ is approximately $10 \%$ high, possibly due to the fact that $\mathrm{MgO}$ and $\mathrm{Na}_{2} \mathrm{O}$ are not estimated. The discrepancy between the $\log$ and core $\mathrm{K}_{2} \mathrm{O}$ measurement is thought to be due to selective sampling of the freshest basalt for XRF measurements, which does not account for the possibility of K-rich clays representing the major alteration minerals at Hole $770 \mathrm{C}$. The upper pillow basalts show a higher $\mathrm{TiO}_{2}$ content than do the lower, more phyric units.

\section{CONCLUSIONS}

The reprocessing of geochemical logs described above converts the measured relative elemental yield into oxide weight fractions that can be used quantitatively for geochemical and lithologic interpretation. When core data is missing, the reprocessed logs are an invaluable data set from which the lithology can be derived and interpreted.

\section{REFERENCES}

Hertzog, R., Colson, B., Seeman, M., O'Brien, H., Scott, D., McKeon, P., Wraight, J., Schweitzer, J., and Herron, M., 1987. Geochemical logging with spectrometry tools. Soc. Pet. Eng. Pap., 16792.

Jarrard, D. R., and Lyle, M., in press. High-resolution geochemical variations at ODP Sites 723, 728, and 731: a comparison of X-ray fluorescence and geochemical logs. In Prell, W. L., Niitsuma, N., et al., Proc. ODP, Sci. Results, 117: College Station (Ocean Drilling Program).

Lock, G. A., and Hoyer, W. A., 1971. Natural gamma ray spectral logging. Log Analyst, 12:3-9.

Ruckebusch, G., 1983. A Kalman filtering approach to natural gamma ray spectroscopy in well logging. Inst. Electr. Electron. Eng. Trans., 28:372-380.

Scott, H. D., and Smith, M. P., 1973. The aluminum activation log. Log Analyst, 14:3-12.

Shipboard Scientific Party, 1990a. Site 767. In Rangin, C., Silver, E. A., et al., Proc. ODP, Init. Repts., 124: College Station, TX (Ocean Drilling Program), 121-193.

1990b. Site 770. In Rangin, C., Silver, E. A., et al., Proc, ODP, Init. Repts., 124: College Station, TX (Ocean Drilling Program), 343-397.

Date of initial receipt: 5 July 1990

Date of acceptance: 26 November 1990

Ms 124B-181 

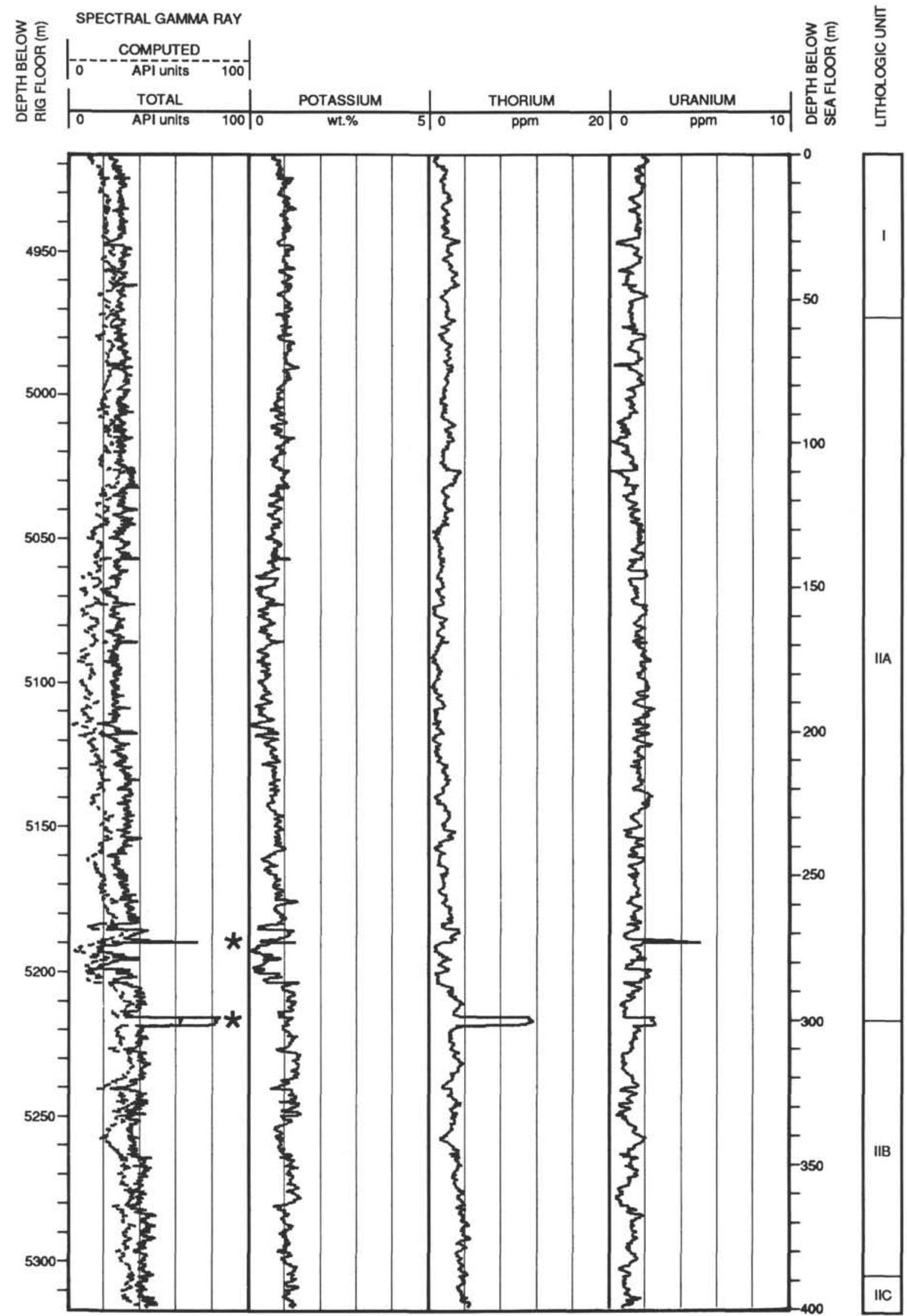

Figure 2. Processed natural gamma-ray data at Hole 767B. Asterisks indicate spikes due to formation activation by the nuclear source of the AACT tool. 


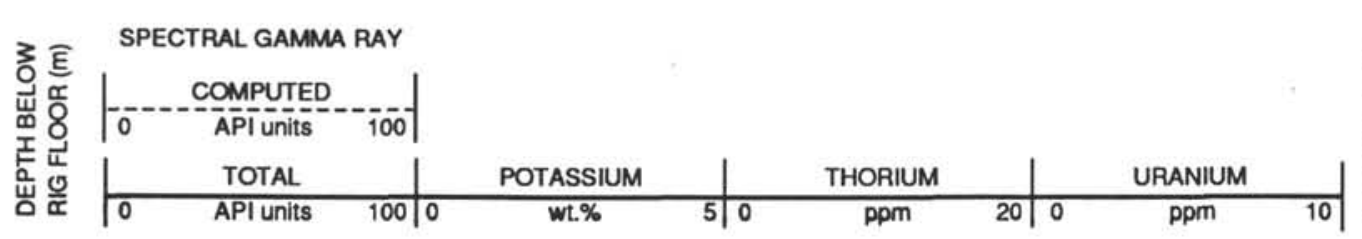

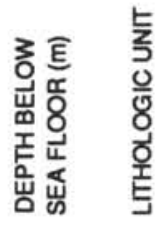

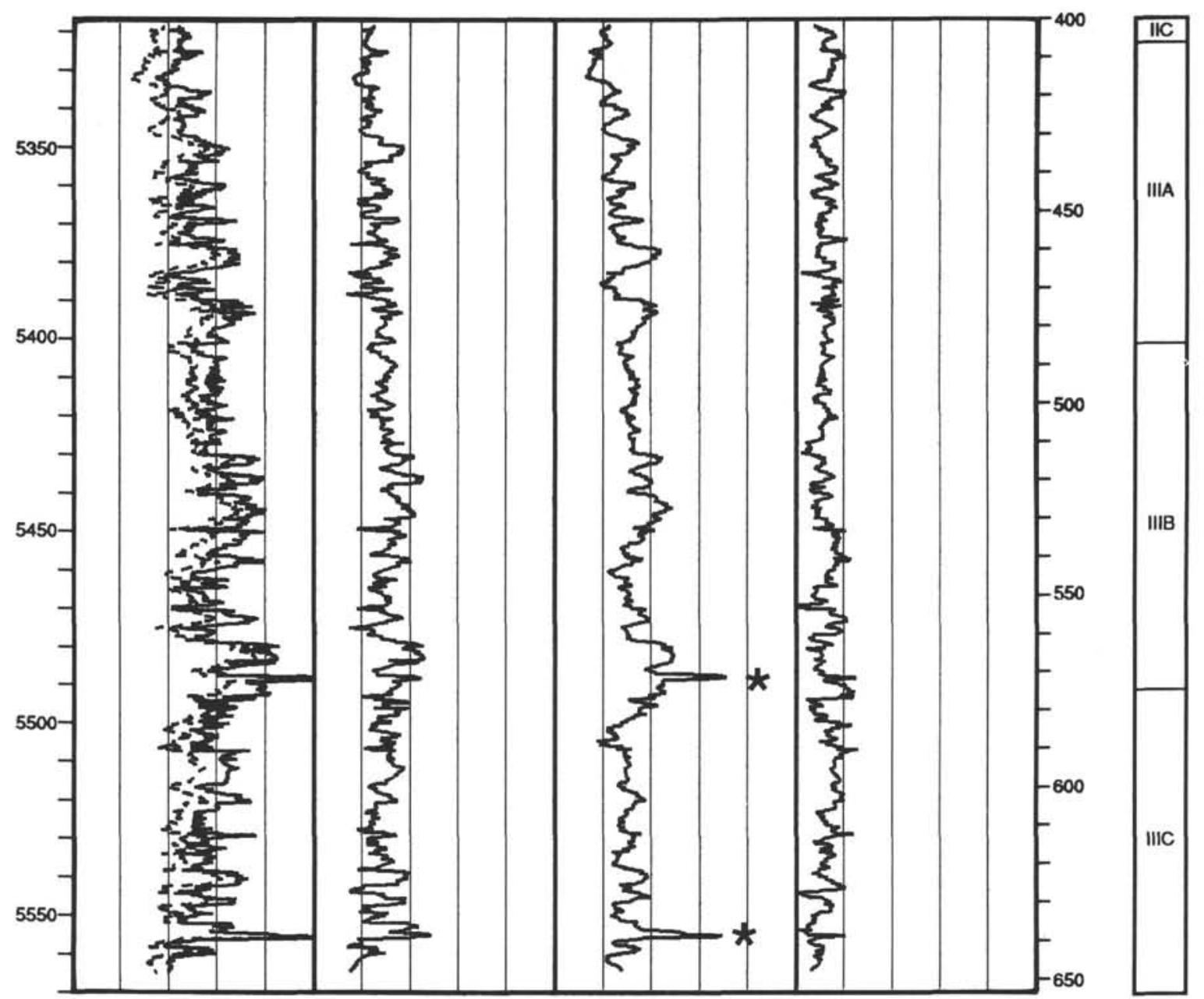

HOLE 767B: LEGEND OF LITHOLOGC UNITS

Unit I: volcanogenic clayey sit with minor volcanic ash

Unit IIA: volcanogenic clayey silt with minor volcanic ash and carbonate turbidites

Unit IIB: volcanogenic clayey silt/siltstone with minor carbonate turbidites

Unit IIC: volcanogenic silty claystone, minor carbonate turbidites and tuff, and

claystone turbidites

Unit IIIA: claystone with claystone/siltstone turbitites and carbonate siltstone

turbidites

Unit IIIB: turbidite claystone, siltstone, and sandstone

Unit IIIC: claystone and silty claystone

Figure 2 (continued). 


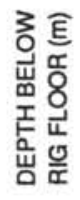

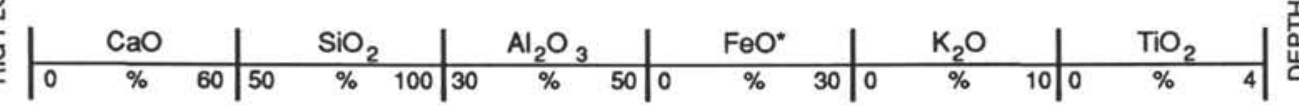
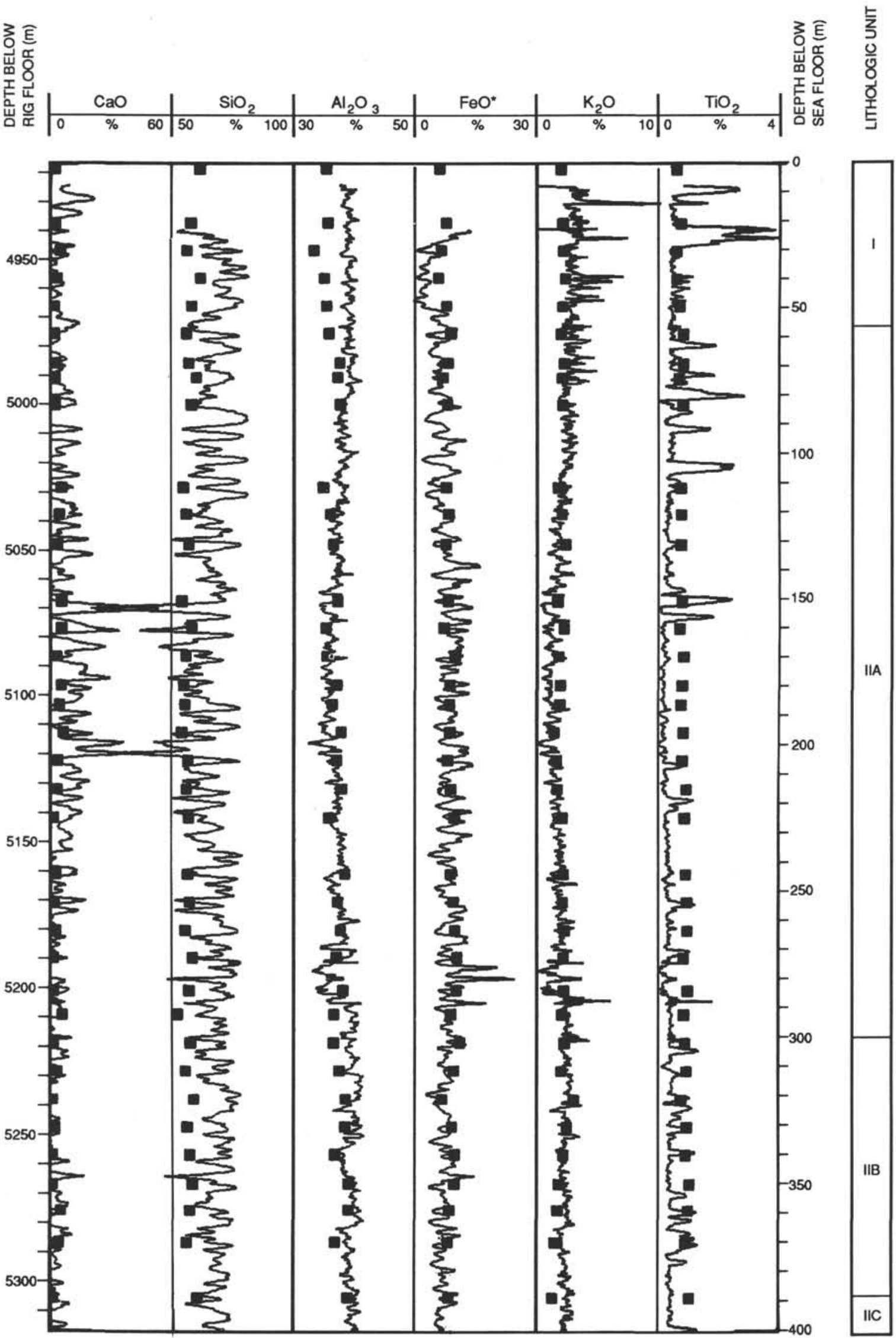

Figure 3. Estimates of the major oxide weight fractions from geochemical logs in Hole 767B. 

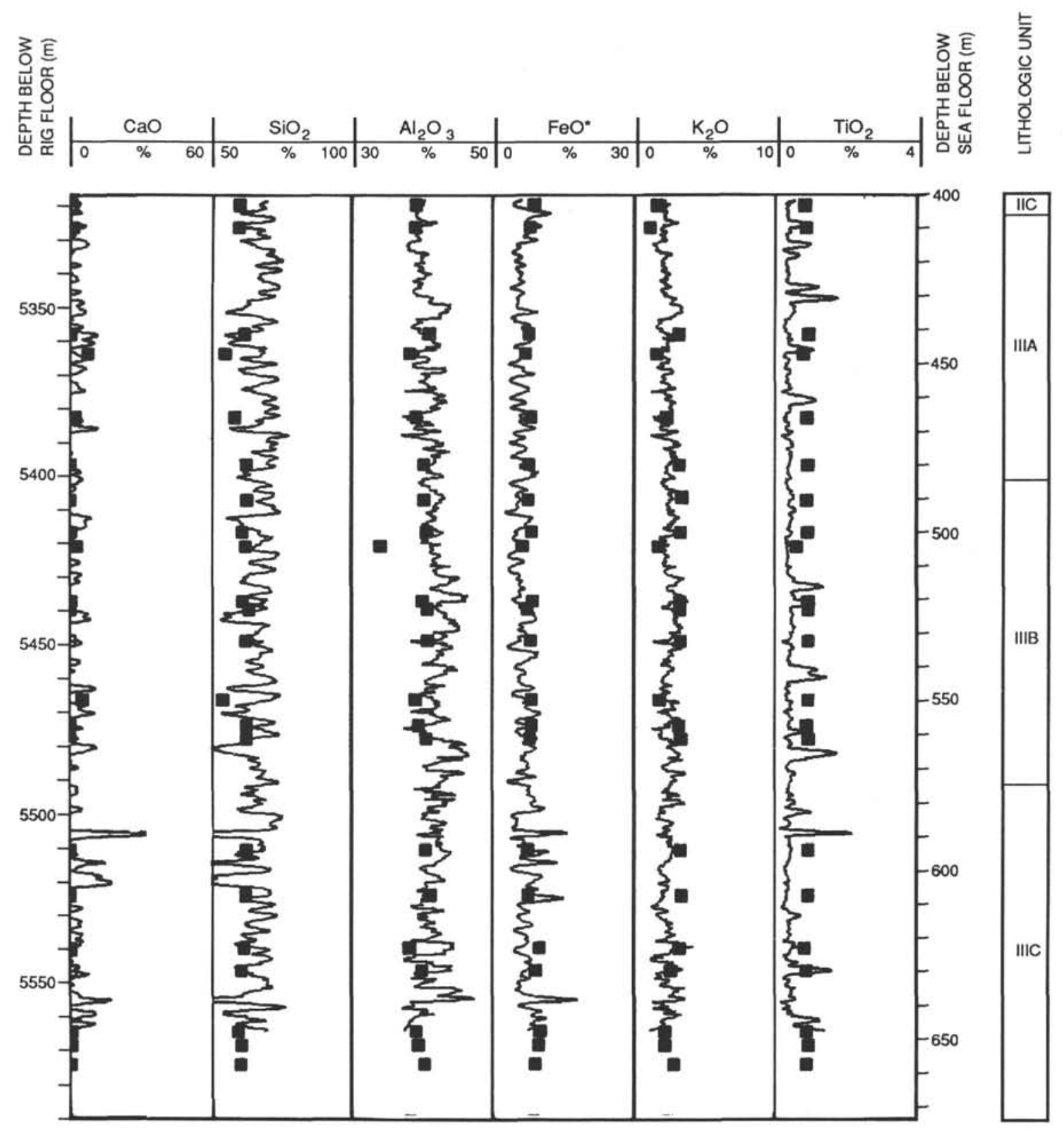

Figure 3 (continued). 

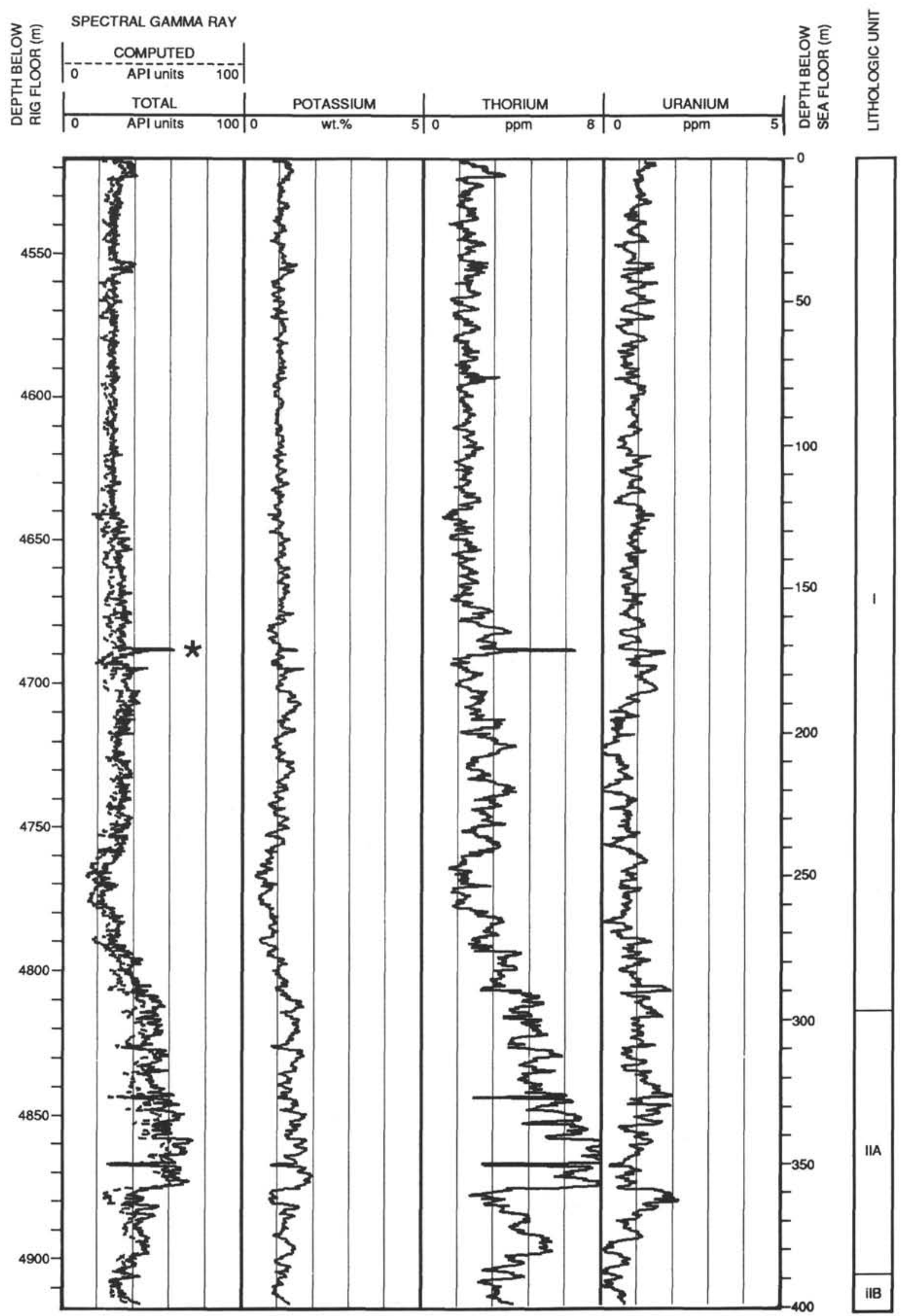

Figure 4. Processed natural gamma-ray data at Hole $770 \mathrm{C}$. Asterisks indicate spikes due to formation activation by the nuclear source of the AACT tool. 

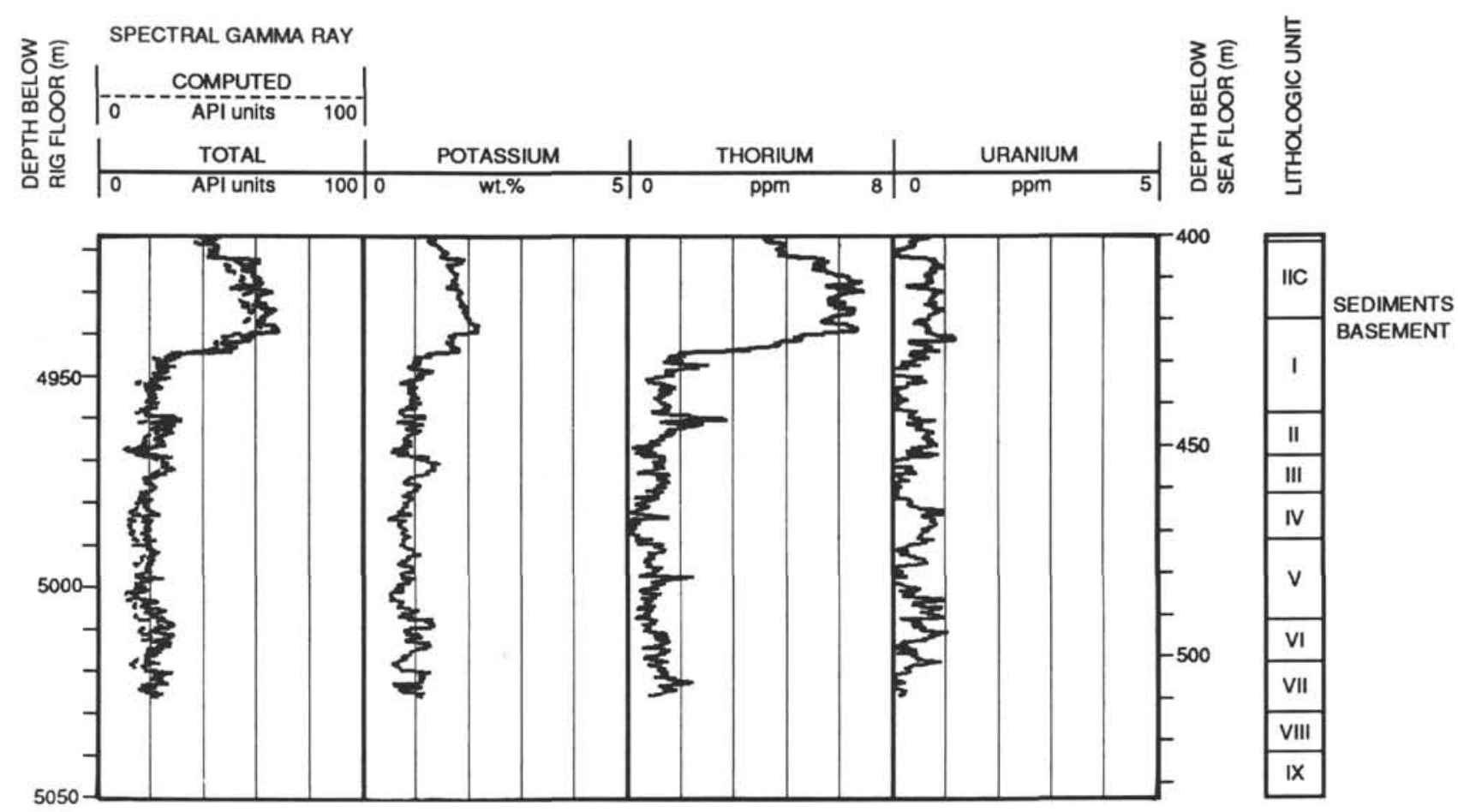

HOLE 770C: LEGEND OF LITHOLOGIC UNITS

\section{Sediments}

Unit I: volcanic silty clay, marl, and volcanic ash

Unit IIA: claystone with minor volcanic claystone, silty claystone, and clayey sand

Unit IIB: nannofossil claystone

Unit IIC: claystone and nannofossil claystone with minor sandy clay and silty claystone

\section{Basement}

Unit I: phyric basalt and pillow lava

Unit II: phyric basalt, pillow lava, and breccia

Unit III: phyric basalt and brecciated lava

Unit IV: phyric basalt and brecciated lava

Unit V: phyric basalt, pillow lava, and breccia

Unit VI: phyric basalt and lava with dikes

Unit VII: aphyric dolerite

Unit VIII: phyric dolerite

Unit IX: basalt and lava with dikes

Figure 4 (continued). 

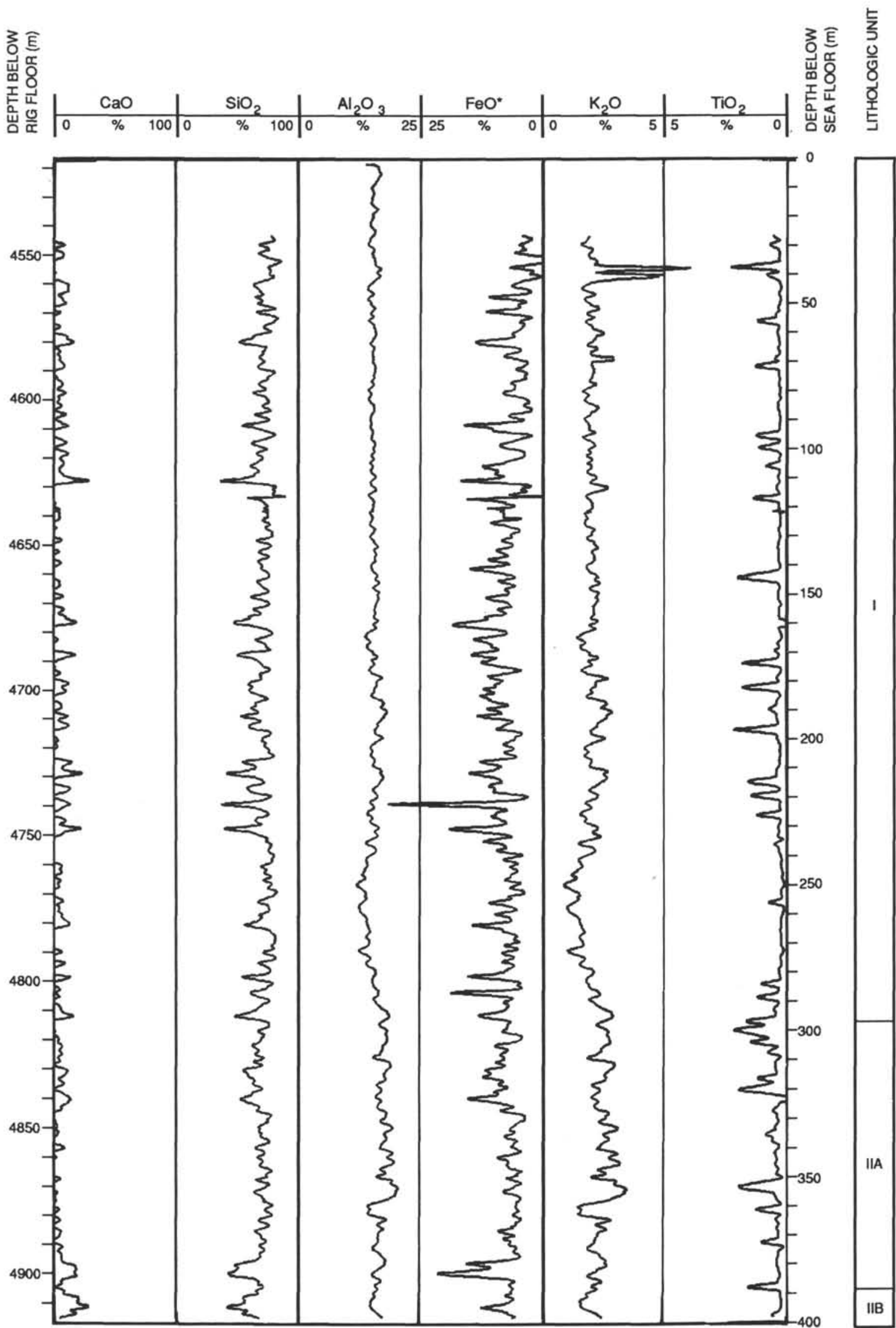

Figure 5. Estimates of the major oxide weight fractions from geochemical logs in Hole 770C. 


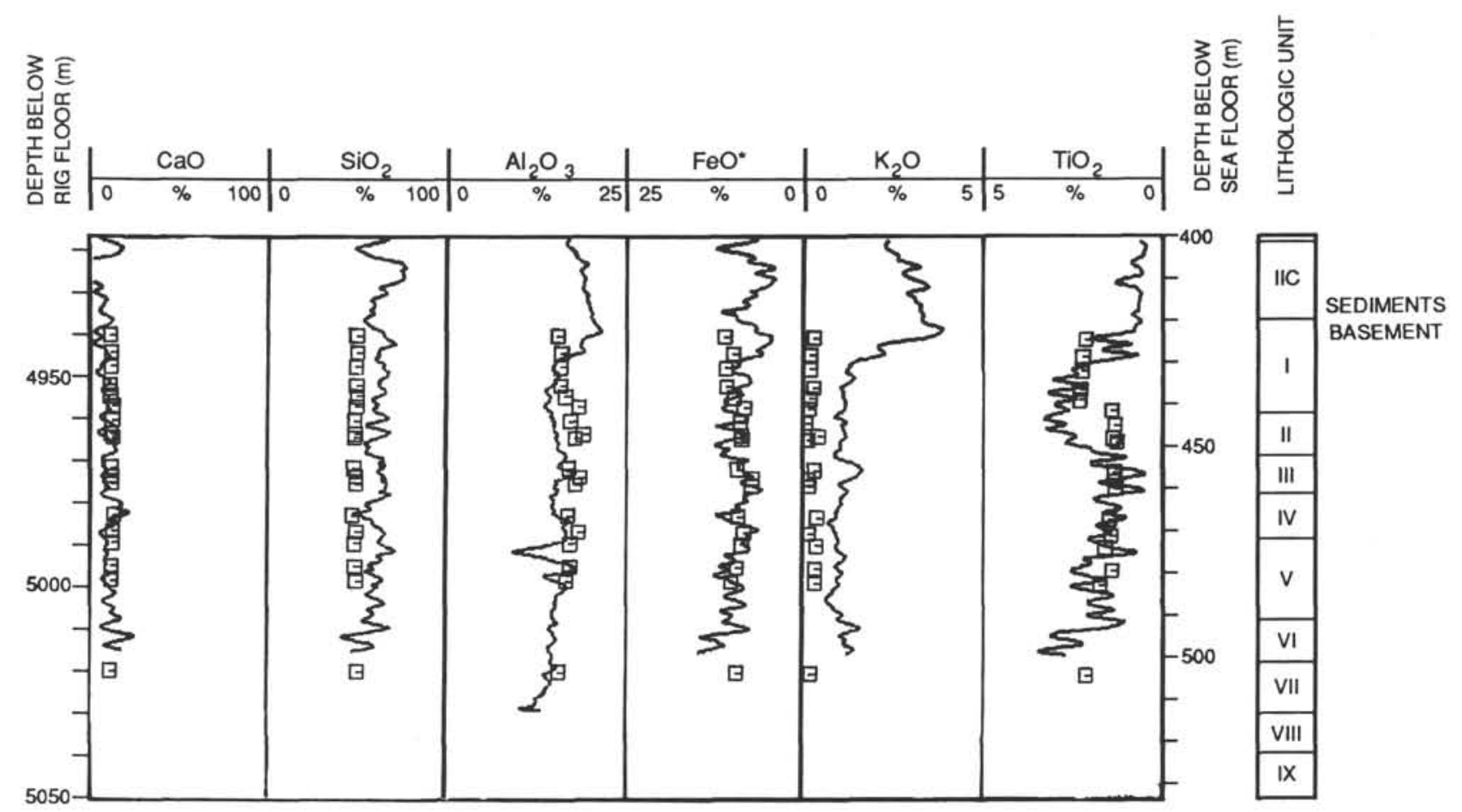

Figure 5 (continued). 